\title{
Inactivated Parapoxvirus ovis as inducer of immunity in silver catfish (Rhamdia quelen)
}

\author{
TATIANA R. PAVAN ${ }^{1}$, CRISTIAN O. NIED ${ }^{1}$, MIRELA NORO ${ }^{2}$, DENIZ ANZILIERO ${ }^{3}$, \\ RAFAEL FRANDOLOSO ${ }^{1}$ and LUIZ CARLOS KREUTZ ${ }^{1}$
}

\author{
${ }^{1}$ Programa de Pós-Graduação em Bioexperimentação, Universidade de Passo Fundo, Laboratório de Microbiologia \\ e Imunologia Avançada, Prédio G3, Campus I, São José, BR 285, Km 292, 99052-900 Passo Fundo, RS, Brasil \\ ${ }^{2}$ Universidade Federal do Pampa, BR 472, Km 592, 97501-970 Uruguaiana, RS, Brasil \\ ${ }^{3}$ Programa de Pós-Graduação em Medicina Veterinária, Departamento de Medicina Veterinária Preventiva, Universidade \\ Federal de Santa Maria, Av. Roraima, 1000, Prédio 20, sala 4200, Camobi, 97105-900 Santa Maria, RS, Brasil
}

Manuscript received on August 5, 2015; accepted for publication on November 27, 2015

\begin{abstract}
Molecules with immune modulating activity are ubiquitously distributed in nature and their impact on aquaculture has been exploited in order to increase fish resistance to pathogens. Here, we investigated the effect of inactivated Parapoxvirus ovis (iPPVO) on blood cells and innate and acquired immune response of silver catfish (Rhamdia quelen). iPPVO inoculation had no effect on respiratory burst activity; however, following iPPVO inoculation, we observed a significant decrease on circulating monocytes concomitantly with an increased number of heterophilic granulocytes and thrombocytes, which are the main cells involved in innate immunity and provide connection with acquired immunity. Fish inoculated with a combination of bovine serum albumin (BSA) + iPPVO had significantly higher levels of antibodies to BSA compared to fish inoculated with BSA alone, but lower than fish inoculated with BSA + Freund's incomplete adjuvant (FIA). These findings points to the potential usefulness of iPPVO as immunomodulator in fish and instigate further research to identify its component that interact with immune cells and that could be exploited as adjuvants in fish.
\end{abstract}

Key words: immunostimulant, adjuvant, antibody, fish.

\section{INTRODUCTION}

Vaccination is becoming a major tool on fish farming and has been the key reason for the dramatic reduction of antibiotic usage in aquaculture (Sommerset et al. 2005). Currently, commercial vaccines are available for several bacterial diseases and ongoing research focus on the development of improved adjuvants and antigens aiming protection

Correspondence to: Luiz Carlos Kreutz

E-mail: lckreutz@upf.br mainly against viral and parasitic diseases (Tafalla et al. 2013). One of the major hurdles associated with fish vaccination concerns to massive production of low-cost and effective antigens and adjuvants. In addition, the route of vaccine administration in fish is also a matter of concern in that protective immune response is usually achieved only following intraperitoneal inoculation of oil-based vaccines, and poses several limitations and risks (Evensen 2009). In this scenario, research on novel, pathogen-associated molecular pattern 
(PAMP) components with adjuvanticity properties are much needed.

The Parapoxvirus ovis (PPVO), also known as orf virus (ORFv), is a large enveloped DNA virus (Haig and McInnes 2002) that contains several genes coding for proteins known to counterattack host immune responses (McGuire et al. 2012) and genes homologues to host cytokines (Fleming et al. 1997). One of the most interesting immunological features observed following infection of sheep with PPVO is the lack of neutralizing antibodies (Haig and McInnes 2002). The immunomodulatory effects of inactivated PPVO (iPPVO) on terrestrial vertebrates has long been reported and demonstrated in vitro and in vivo (Castrucci et al. 2000, Fachinger et al. 2000, Fleming et al. 1997, Kyriakis et al. 1998, Paillot 2013, Schütze et al. 2009), and recently detailed in a murine model in which we showed that iPPVO inoculation in mice resulted in a coordinated overexpression of proinflammatory and Th1 cytokines up to $96 \mathrm{~h}$ post inoculation (Anziliero et al. 2014a, b), and improved innate immune response mediated by respiratory burst, phagocytosis and serum bactericidal activity.

In fish, molecules that interact with immune cells and mediate natural and acquired defense mechanisms are in great demand and research on this subject has increased significantly in the last decade. Most molecules with immune stimulating properties are derived from herbs, roots and microorganisms, mainly bacteria and fungi (Bairwa et al. 2012, Maqsood et al. 2011, Van Hai 2015). Studies concerning the immunological effect of viral-derived proteins in fish are scarce. A single study indicated that rainbow trout (Oncorhyncus mykiss) treated with iPPVO had reduced clinical signs following infection with Aeromonas salmonicida, the etiological agent of furunculosis (Ortega et al. 1996). Here, the major goals were to investigate the effect of iPPVO on respiratory burst activity, innate immune cells and serum antibody response in silver catfish (Rhamdia quelen), a teleost fish ubiquitous in South American rivers and lakes.

\section{MATERIALS AND METHODS}

FISH

Silver catfish $(50-80 \mathrm{~g})$ of both sexes were acclimatized in self-cleaning tanks containing 1000 $\mathrm{L}$ of continuously running water (15 fish/tank) and used in this study. Fish were fed twice daily with commercial fish pellets $(42 \%$ crude protein, Supra, Brazil). Water parameters measured during the experiment were as follows: dissolved oxygen $7.8 \pm 0.4 \mathrm{mg} / \mathrm{L}$; total ammonia was lower than 0.01 $\mathrm{mg} \mathrm{l}^{-1}$ and total hardness and alkalinity were 66 and $22 \mathrm{mg} \mathrm{l}^{-1} \mathrm{CaCO}_{3}$, respectively.

\section{EXPERIMENTAL DESIGN}

Inactivated PPVO was prepared as previously described (Anziliero et al. 2014a) and stored at a titer of $1 \times 10^{8}$ Plaque Forming Unit (PFU)/ml. A dose of $100 \mu \mathrm{l}$ of iPPVO or sterile phosphate buffered saline (PBS), inoculated by intramuscular route, was used throughout the study. In the first experiment, groups of fish were inoculated with iPPVO or equivalent volume of sterile PBS, and blood samples were collected at $24 \mathrm{~h}$ post inoculation to determine the respiratory burst activity, or at 3,5 and 7 days post inoculation to determine hematological parameters. Concomitantly, in a second experiment, 5 groups of fish were inoculated with: I) sterile PBS; II) iPPVO; III) Bovine Serum Albumin (BSA, 200 $\mu \mathrm{g}$ / fish for all inoculations; Sigma); IV) BSA+iPPVO; V) BSA+ Freund's Incomplete Adjuvant (FIA). Blood samples were collected at 35 days post inoculation to measure the production of specific antibodies. Fish inoculation and sample collection were performed in fish anesthetized with Eugenol $(50 \mathrm{mg} / \mathrm{L})$. The experiments were approved by the Ethical and Animal Welfare Committee of the Universidade de Passo Fundo (Protocol number 003/2011) 


\section{RESPIRATORY BURST ACTIVITY}

The nitroblue tetrazolium (NBT) method was used to estimate the production of intracellular superoxide radicals on whole blood samples, as reported previously (Behera et al. 2010). Briefly, $100 \mu \mathrm{l}$ of heparinized blood was mixed with 100 $\mu 1$ of $0.2 \%$ NBT (Sigma) and incubated at $25^{\circ} \mathrm{C}$ for $30 \mathrm{~min}$. Then, $50 \mu \mathrm{l}$ of the blood NBT solution was mixed to $1 \mathrm{ml}$ of $\mathrm{N}, \mathrm{N}$ diethylmethyl formamide (Sigma), centrifuged (6000 x g, $5 \mathrm{~min}$ ) and the optical density of the supernatant was measured at $540 \mathrm{~nm}$

\section{HEMATOLOGICAL PARAMETERS}

Heparinized blood samples were collected from the caudal vein and blood smear were prepared immediately after sampling, air-dried and stained with Wright-Giemsa, to differentiate leukocytes and thrombocytes. Erythrocytes and leukocytes were counted using an improved Neubauer chamber following standard protocols. Hematocrit and hemoglobin counts were determined on whole blood within $2 \mathrm{~h}$ after sampling, as previously described (Kreutz et al. 2011). Total plasma protein was determined using a refractometer.

\section{ENZYME-LINKED IMMUNOSORBENT ASSAY TO DETECT ANTI-BSA ANTIBODIES}

A triple antibody indirect ELISA was carried out to detect silver catfish antibodies to BSA. Briefly, $100 \mu \mathrm{l}$ of BSA $(50 \mu \mathrm{g} / \mathrm{ml})$ in carbonate-bicarbonate buffer (15 mM, pH 9.5) were distributed in 96well plates and incubated for $24 \mathrm{~h}$ at $4^{\circ} \mathrm{C}$. Then, the BSA solution was removed and the wells blocked with 3\% skim milk (SK, Sigma) diluted in PBS containing $0.05 \%$ Tween-20 (PBS-T) for $1 \mathrm{~h}$ at $23^{\circ} \mathrm{C}$. The blocking solution was removed and silver catfish serum, diluted 1:100 in PBS-T, 1\% SK, was added to the plates as first antibody. The plates were incubated at $23^{\circ} \mathrm{C}$ for $1 \mathrm{~h}$, washed four times with PBS-T and allowed to react with rabbit anti-silver catfish IgM-like immunoglobulin diluted 1:1000 as the second antibody, for $1 \mathrm{~h}$ at $23^{\circ} \mathrm{C}$. After four washes, goat anti-rabbit peroxidase conjugated (third antibody, Sigma) diluted 1:20.000 was added and incubated for $1 \mathrm{~h}$ at $23^{\circ} \mathrm{C}$. Plates were then washed four times and incubated with $100 \mu$ of substrate solution (5 mg of O-phenylene diamine tetra dihydrochloride in $10 \mathrm{ml}$ of acetate buffer, $\mathrm{pH}$ 5.0, containing $4 \mu \mathrm{l}$ of $30 \% \mathrm{H}_{2} \mathrm{O}_{2}$ ) for $15 \mathrm{~min}$ in the dark. The reaction was stopped by adding $50 \mu 1$ of $3 \mathrm{M}$ hydrochloric acid and measured in an ELISA reader at $450 \mathrm{~nm}$ (Biochrom Anthos).

STATISTICAL ANALYSIS

The data obtained was analyzed by the ShapiroWilk's test and were found to have normal distribution. Differences amongst treatments were analyzed by t-test or two-way ANOVA followed by Bonferroni's multiple comparisons test, as indicated on the table and figure legends, and plotted using Prism GraphPad Prism Software v. 5. $P$-values of 0.05 or smaller were considered significant. Results are expressed as the mean \pm standard error of the mean (S.E.M.).

\section{RESULTS AND DISCUSSION}

The immune modulating activity of iPPVO suggests the existence of a complex group of proteins in the viral structure that interact with host immune cells and might be exploited as potential adjuvants for the prophylaxis of animal diseases or as vaccine adjuvants. In a previous study we demonstrated that iPPVO induced a transient but significant increase in respiratory burst of murine neutrophils, and several proinflammatory and auto regulatory cytokines in mice (Anziliero et al. 2014a). Here, we investigated the effect of iPPVO on some immune parameters of silver catfish. iPPVO had no effect on respiratory burst activity when measured in total blood cells at $24 \mathrm{~h}$ post inoculation (Figure 1). Similarly, no effect on the respiratory burst of total 


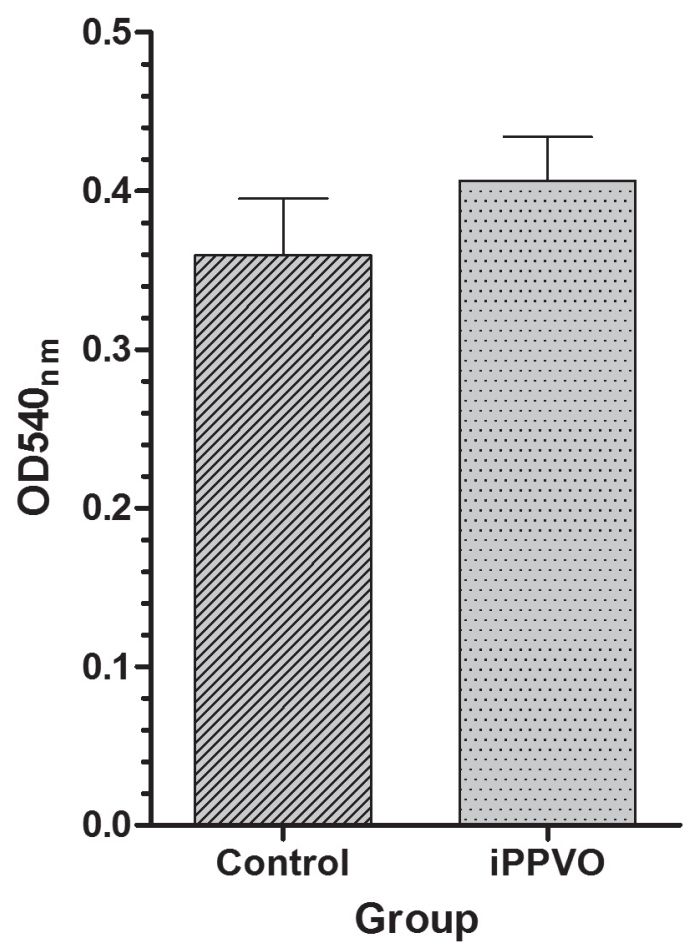

Figure 1 - Respiratory burst activity measured on blood cells collected from silver catfish $24 \mathrm{~h}$ after inoculation with PBS or iPPVO. Data represent the means \pm S.E.M. $(n=15)$ and were compared using $\mathrm{t}$-test. There were no significant differences $(\mathrm{p}<0.05)$ between groups.

blood cells was also reported in a porcine model (Fachinger et al. 2000). In contrast, when iPPVO was incubated with purified canine monocytes (Schütze et al. 2009) and human neutrophils (Friebe et al. 2004) a significant increase in the respiratory burst activity was observed. It should not be assumed, however, that fish cells do not recognized iPPVO; at contrary, the absence of a measurable effect could be related to the fact that we used total blood cells and it instigates investigation of the possible effect and interaction of iPPVO with purified blood cells and cells from head and middle kidney cells. In most mammal species, iPPVO is an inducer of proinflammatory (TNF- $\alpha$, IL- $1 \beta$ and IL-8) and Th1-derived cytokines (Anziliero et al. 2014b), and the increase on respiratory burst might be the result of direct interaction of iPPVO with innate immune cells and also as the result of cytokine (TNF- $\alpha$ ) stimulation of pre-activated phagocytic cells (Forlenza et al. 2011, Mulero et al. 2005). On the other hand, because of the transient and timely effect of iPPVO on cells, it is possible that silver catfish blood cells were activated but at the time we sampled the fish ( $24 \mathrm{~h}$ post inoculation) the production of reactive oxygen species was lowering, as observed in the murine model (Anziliero et al. 2014a), or not yet high enough to be detected in our assay. Nonetheless, because fish pleiotropic cytokines TNF- $\alpha$ and IL- $1 \beta$ are both induced by leucocytes-exposed PAMPs, future investigation with isolated cell population should indicate the stimulating role of iPPVO and its potential use as innate immune modulator in fish.

The number of circulating monocytes 3 days post inoculation with iPPVO was significantly reduced $(p<0.05)$ compared to mock inoculated fish (Table I). Circulating monocytes are driven to the site of antigen injection and comprise the first and perhaps the most important cells of the innate immune system of fish and central to lymphocyte stimulation by means of cytokine production (Forlenza et al. 2011). Heterophilic granulocytes and thrombocytes, in contrast, were significantly higher in iPPVO inoculated fish $(\mathrm{p}<0.05)$ at 5 and 7 days post inoculation, respectively. The remaining hematological parameters were similar between groups and within the range expected for this species (Kreutz et al. 2011). There was no difference in the values of total plasma protein (data not shown). In fish, heterophils and thrombocytes have phagocytic function and play a key role on innate defense towards pathogen infection (Hill and Rowley 1998, Tosik et al. 2001). It is tempting to speculate that the higher number of heterophils and thrombocytes observed in iPPVO inoculated fish could have been the result of the cytokine cascade resulting from the monocytes in contact with iPPVO at the injection site. Because the nucleotide sequence of immune related genes are not available to Rhamdia quelen, a thoroughly analysis of gene expression 
TABLE I

Hematological parameters of silver catfish inoculated with phosphate buffered saline (PBS) or inactivated Parapoxvirus ovis (iPPVO). Blood samples were collected from all inoculated fish $(\mathrm{n}=15)$ at the indicated time. Data represent the mean \pm S.E.M. Differences between the PBS and iPPVO group at 3 days post inoculation are indicated by small letters and differences $(p<0.05)$ within the iPPVO group at each time point are indicated by capital letters.

\begin{tabular}{|c|c|c|c|c|}
\hline \multirow{3}{*}{ Blood parameter } & \multicolumn{4}{|c|}{ Treatment group (days post inoculation) } \\
\hline & \multirow{2}{*}{$\begin{array}{c}\text { PBS } \\
3\end{array}$} & \multicolumn{3}{|c|}{ iPPVO } \\
\hline & & 3 & 5 & 7 \\
\hline Erythrocytes $\left(10^{6} / \mu 1\right)$ & $2.1( \pm 0.14)$ & $2.0( \pm 0.17)$ & $1.8( \pm 0.09)$ & $1.8( \pm 0.19)$ \\
\hline Hemoglobin (g/l) & $109( \pm 8.9)$ & $103( \pm 4.5)$ & $133( \pm 3.8)$ & $121( \pm 5.4)$ \\
\hline Hematocrit (\%) & $42( \pm 2.6)$ & $36( \pm 1.5)$ & $37( \pm 2.0)$ & $40( \pm 1.5)$ \\
\hline Leucocytes $(\mu \mathrm{l})$ & $30058( \pm 3359)$ & $34946( \pm 7619)$ & $34946( \pm 7619)$ & $29470( \pm 5934)$ \\
\hline Heterophils $(\mu 1)$ & $2245( \pm 700)$ & $3087( \pm 1339)^{\mathrm{A}}$ & $19245( \pm 4011)^{\mathrm{B}}$ & $5343( \pm 1992)^{\mathrm{A}}$ \\
\hline Eosinophils $(\mu 1)$ & 0 & 0 & 0 & 0 \\
\hline Monocytes $(\mu 1)$ & $1097( \pm 328)^{\mathrm{a}}$ & $362( \pm 133)^{b}$ & $214( \pm 105)$ & $131( \pm 59)$ \\
\hline Lymphocytes $(\mu \mathrm{l})$ & $11719( \pm 1942)$ & $16693( \pm 7208)$ & $7807( \pm 1762)$ & $4218( \pm 1294)$ \\
\hline Thrombocytes $(\mu \mathrm{l})$ & $31085( \pm 2454)$ & $34339( \pm 5703)^{\mathrm{A}}$ & $31199( \pm 7061)^{\mathrm{A}}$ & $56799( \pm 3397)^{\mathrm{B}}$ \\
\hline
\end{tabular}

could not be performed at this time. However, future investigation on the expression of selective immune-related genes by iPPVO stimulated silver catfish cells should provide a better understanding on this subject.

Beside their pivotal role on first line of defense, innate immune cells (e.g. monocytes), and the recently recognized fish dendritic cells (Bassity and Clark 2012), are fundamental to the development of acquired immunity. Thus, we sought to investigate if antibody production to a specific antigen (BSA) was also affected in iPPVO inoculated fish. Indeed, anti-BSA antibodies in $\mathrm{BSA}+\mathrm{iPPVO}$ vaccinated fish was significantly higher $(\mathrm{p}<0.05)$ compared to the fish inoculated with BSA alone (Figure 2), but lower than from fish inoculated with BSA+FIA. Because the main goal of this work was to investigate a possible adjuvanticity effect of iPPVO, the kinetics of antiBSA antibody production during the experiment was not performed. Nonetheless, because the main effects of iPPVO have been studied mostly on innate immunity, the adjuvanticity effect of iPPVO reported herein is a novel finding, at least in a fish model. The mechanisms behind the increased antibody production might also be related to the pleiotropic cytokines induced by the innate immune cells that interact with iPPVO. In a murine model, proinflammatory (IFN- $\alpha$, IL-1 $\beta$, IL-8), Th1 (IFN- $\gamma$, IL-12), and regulatory Th2 (IL-4 and IL10) cytokines were transiently up regulated in vivo within $96 \mathrm{~h}$ post iPPVO inoculation (Anziliero et al. 2014a, b). A similar pattern of cytokine up regulation was also observed in porcine and human peripheral blood mononuclear cells (Fachinger et al. 2000, Friebe et al. 2004). This intricate network of cytokine production mediated by iPPVO might indeed affect the production of antibodies. IFN type I $(\alpha / \beta)$, for instance, up regulated the expression of MHC class II molecules (Schütze et al. 2009) that mediate epitope presentation to B-lymphocytes. In addition, IL- $1 \beta$ mediates activation of $T$ and B lymphocytes, and IL-4 stimulates antibody production by B cells, whereas IL-2 is well known for its role on clonal expansion of lymphocytes (Stetson and Medzhitov 2006, Swanson et al. 2010). Furthermore, in a porcine model, T helper cells responded to iPPVO administration and were found to be the main source of the increased levels of IL-2, IFN- $\alpha$ and IFN- $\gamma$ (Fachinger et al. 2000). Thus, iPPVO stimulates cytokine-producing innate immune cells which in turn provide the stimuli and 


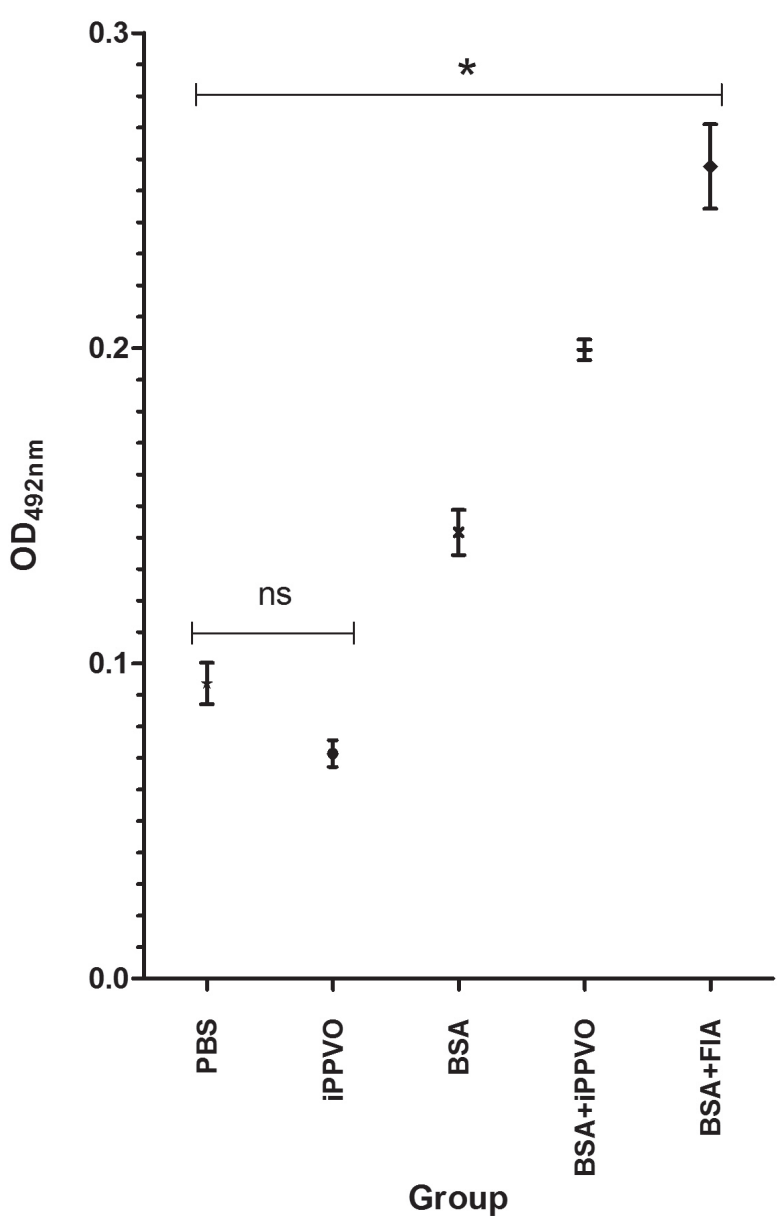

Figure 2 - Anti-BSA antibody production in silver catfish. Fish were inoculated with phosphate buffered saline (PBS), iPPVO, BSA, BSA + iPPVO or BSA + FIA. Serum samples were collected 35 days p.i. and anti-BSA antibody titers measured by ELISA. Data represent the means \pm S.E.M. $(n=15)$ and were compared using two-way ANOVA and Bonferroni posttest. Significant differences $(\mathrm{p}<0.05)$ amongst groups are indicated by asterisk.

support to the development of adaptive, antigenspecific immune response.

In summary, we demonstrate for the first time in fish that iPPVO alters circulating immune cells and improves the secretion of antibodies to a specific antigen. Future studies should investigate the innate immune cells that interact with IPPVO and the immune-related genes expressed both in vivo and in vitro and their correlation with protection to an infecting pathogen.

\section{ACKNOWLEDGMENTS}

This work was carried out using financial support from the Conselho Nacional de Desenvolvimento Científico e Tecnológico (CNPq), Brazil; grant no 476317/2012-6. Tatiana R. Pavan is a Master Student with a Coordenação de Aperfeiçoamento de Pessoal de Nível Superior (CAPES) fellowship (\#2013/1236). Cristian O. Nied is an undergraduate student with a CNPq fellowship (125852/2013-4).

\section{REFERENCES}

ANZILIERO D, KREUTZ LC, FLORES EF AND WEIBLEN R. 2014a. Effects of inactivated Parapoxvirus ovis on cellular and humoral events of the innate immune response in mice. Cell Immunol 289: 36-41.

ANZILIERO D, WEIBLEN R, KREUTZ LC, SPILKI F AND FLORES EF. 2014b. Inactivated Parapoxvirus ovis induces a transient increase in the expression of autoregulatory cytokines in mice. Brazilian J Med Biol Res 47: 110-118.

BAIRWA MK, JAKHAR JK, SATYANARAYANA Y AND REDDY D. 2012. Animal and plant originated immunostimulants used in aquaculture. J Nat Prod Plant Resour 2: 397-400.

BASSITY E AND CLARK TG. 2012. Functional identification of dendritic cells in the teleost model, rainbow trout (Oncorhynchus mykiss). PLoS One 7: e33196.

BEHERA T, NANDA PK, MOHANTY C, MOHAPATRA D, SWAIN P, DAS BK, ROUTRAY P, MISHRA BK AND SAHOO SK. 2010. Parenteral immunization of fish, Labeo rohita with Poly D, L-lactide-co-glycolic acid (PLGA) encapsulated antigen microparticles promotes innate and adaptive immune responses. Fish Shellfish Immunol 28 : 320-325.

CASTRUCCI G, OSBURN BI, FRIGERI F, FERRARI M, SALVATORI D, LO DICO M AND BARRECA F. 2000. The use of immunomodulators in the control of infectious bovine rhinotracheitis. Comp Immunol Microbiol Infect Dis 23: 163-173.

EVENSEN Ø. 2009. Development in fish vaccinology with focus on delivery methodologies, adjuvants and formulations. Options Méditerranéennes A 86: 177-186.

FACHINGER V, SCHLAPP T, STRUBE W, SCHMEER N AND SAALMÜLLER A. 2000. Poxvirus-induced immunostimulating effects on porcine leukocytes. J Virol 74: 7943-7951.

FLEMING SB, MCCAUGHAN CA, ANDREWS AE, NASH AD AND MERCER AA. 1997. A homolog of interleukin-10 is encoded by the poxvirus orf virus. J Virol 71: 4857-4861.

FORLENZA M, FINK IR, RAES G AND WIEGERTJES GF. 2011. Heterogeneity of macrophage activation in fish. Dev Comp Immunol 35: 1246-1255. 
FRIEBE A, SIEGLING A, FRIEDERICHS S, VOLK H AND WEBER O. 2004. Immunomodulatory Effects of Inactivated Parapoxvirus ovis ( Orf Virus ) on Human Peripheral Immune Cells : Induction of Cytokine Secretion in Monocytes and Th1-Like Cells. J Virol 78: 9400-9411.

HAIG M AND MCINNES CJ. 2002. Immunity and counterimmunity during infection with the parapoxvirus orf virus. Virus Res 88: 3-16.

HILL DJ AND ROWLEY AF. 1998. Are integrins involved in the aggregatory and phagocytic behaviour of fish haemostatic cells? J Exp Biol 201: 599-608.

KREUTZ LC, BARCELLOS LJG, DE FARIA VALLE S, DE OLIVEIRA SILVA T, ANZILIERO D, DAVI DOS SANTOS E, PIVATO M AND ZANATTA R. 2011. Altered hematological and immunological parameters in silver catfish (Rhamdia quelen) following short term exposure to sublethal concentration of glyphosate. Fish Shellfish Immunol 30: 51-57.

KYRIAKIS SC, TZIKA ED, LYRAS DN, TSINAS AC, SAOULIDIS K AND SARRIS K. 1998. Effect of an inactivated Parapoxvirus based immunomodulator (Baypamun) on post weaning diarrhoea syndrome and wasting pig syndrome of piglets. Res Vet Sci 64: 187-190.

MAQSOOD S, SINGH P, SAMOON MH AND MUNIR K. 2011. Emerging role of immunostimulants in combating the disease outbreak in aquaculture. Int Aquatic Res 3: 147-163.

MCGUIRE MJ, JOHNSTON SA AND SYKES KF. 2012. Novel immune-modulator identified by a rapid, functional screen of the Parapoxvirus ovis (Orf virus) genome. Proteome Sci 10: 4.

MULERO V, AYALA AG AND MESEGUER J. 2005. What can we learn from fish? An evolutionary perspective of pro-inflammatory cytokines. Inmunología 24: 17-22.
ORTEGA C, RUIZ I, DE BLAS I, MUZQUIZ JL, FERNANDEZ A AND ALONSO JL. 1996. Furunculosis control using a paraimmunization stimulant (Baypamun) in rainbow trout. Vet Res 27: 561-568.

PAILLOT R. 2013. A systematic review of the immunemodulators Parapoxvirus ovis and Propionibacterium acnes for the prevention of respiratory disease and other infections in the horse. Vet Immunol Immunopathol 153: 1-9.

SCHÜTZE N, RAUE R, BÜTTNER M AND ALBER G. 2009. Inactivated Parapoxvirus ovis activates canine blood phagocytes and T lymphocytes. Vet Microbiol 137: 260-267.

SOMMERSET I, KROSSØY B, BIERING E AND FROST P. 2005. Vaccines for fish in aquaculture. Expert Rev. Vaccines 4: 89-101.

STETSON DB AND MEDZHITOV R. 2006. Type I interferons in host defense. Immunity 25: 373-381.

SWANSON CL, WILSON TJ, STRAUCH P, COLONNA M, PELANDA R AND TORRES RM. 2010. Type I IFN enhances follicular B cell contribution to the T cellindependent antibody response. J Exp Med 207: 14851500.

TAFALLA C, BØGWALD J AND DALMO RA. 2013. Adjuvants and immunostimulants in fish vaccines: Current knowledge and future perspectives. Fish Shellfish Immunol 35: 1740-1750.

TOSIK MS, EPTULA WD AND RÁVNIÈEK MT. 2001. Studies on the number and ingesting ability of thrombocytes in sick carps (Cyprinus carpio L.). Vet Med - Czech 46: $12-16$.

VAN HAI N. 2015. The use of medicinal plants as immunostimulants in aquaculture: A review. Aquaculture 446: 8896. 